\title{
A Novel Extractive Spectrophotometric Method for The Determination Of Chromium In Water Samples
}

\author{
K.Kiran \\ Department of Environmental Sciences, Sri Venkateswara University, Tirupati, A.P. INDIA,
}

\begin{abstract}
: m-hydroxy benzyl ethylene diamine synthesized by the author in the laboratory has been successfully used as a reagent to form complex with chromium metal in water samples. The estimation of chromium present in various water samples has been carried out by spectrophotometry. Other parameters like effect of $p H$, reagent concentration, choice of solvent, effect of interference ions has been studied. . This method is simple, sensitive and accuracy comparable with other existing extractive spectrophotometric methods for the determination of Chromium in various water samples.
\end{abstract}

Keywords: Chromium,m-hydroxybenzylethylenediamine,watersamples

\section{Introduction}

Chromium plays an important physiological role in all animals including human beings. Chromium is present in many pharmaceutical samples and in airborne particulates, causing environmental pollution. The concentration of $\mathrm{Cr}$ in natural waters is very low [1,2]. The determination of chromium in water is also of considerable interest. $\mathrm{Cr}(\mathrm{III})$ is an essential component having an important role in the glucose, lipid and protein metabolism, while $\mathrm{Cr}(\mathrm{VI})$ has a definitely adverse impact on living organisms. $\operatorname{Cr}(\mathrm{VI})$ can easily penetrate the cell wall and exert its noxious influence in the cell itself, being also a source of various cancer diseases $[3,4]$. One of the routes of $\mathrm{Cr}$ incorporation into the human body is by ingestion [5,6]. Several analytical methods have been developed in order to separate and determine $\mathrm{Cr}(\mathrm{III})$ and $\mathrm{Cr}(\mathrm{VI})$ species in water samples [4,5]. Various preconcentration procedures for the determination of chromium have been reported [6-10, 12-16], including, among others, chelation, precipitation, co-precipitation, liquid-liquid extraction and ion-exchange. Revanasiddappa etal [11] developed a rapid and sensitive spectrophotometric method for the determination of trace amounts of chromium(VI). The method is based on the oxidation of trifluoperazine hydrochloride (TFPH) by chromium(VI) in the presence of orthophosphoric acid. Spectrophotometric determination of chromium(VI) as the familiar blue chromium-peroxo complex is well known [ 8,9]. In the present study, the author used $m$ hydroxy benzyl ethylene diamine which is synthesized in the laboratory for successful application for the determination of chromium in various water samples.

\section{Experimental}

All starting materials required for the preparation of the reagent were of analytical reagent grade. All the solvents used were double distilled before use. These included chloroform, methyl isobutyl ketone, carbon tetrachloride, benzene, $n$-butyl alcohol, amyl alcohol, dimethylformamide and ethyl alcohol. Reagents, standard solutions of metal ions and various other solutions required in the present investigations have been prepared daily by following the standard procedures.

\subsection{Procedure for the Synthesis of ligand}

$1.0 \mathrm{~g}$ of $m$-hydroxy benzaldehyde was dissolved in $25 \mathrm{ml}$ of double distilled water and mixed in a flask with $1.0 \mathrm{~g}$ of 4 -amino benzoic acid and refluxed for 3 hours. A pale yellow colored crystal product was appears. Filtered the product and dried at room temperature. Finally the product was recrystallized by using ethanol. The resulting product has melting point of $165^{\circ} \mathrm{C}$ and the yield was $80-90 \%$. The above reaction was shown in Fig.1.

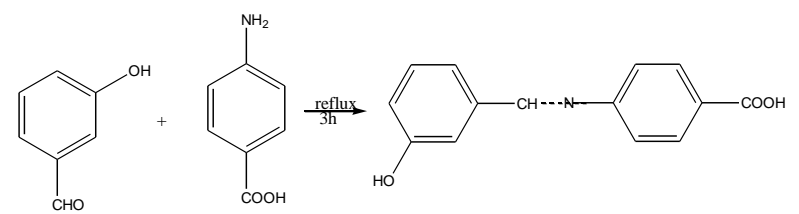

Fig.1. Schematic diagram of $\boldsymbol{m}$-hydroxy benzyl aminobenzoic acid

The reagent solution was prepared in forty percent dimethylformamide (aqueous) solution. This reagent solution is stable for more than four hours. A digital pH meter, Model LI-120 (ELICO), with combined 
glass electrode assembly was employed for reckoning $\mathrm{pH}$ studies. The sensitivity of the instrument was \pm 0.001 $\mathrm{pH}$ units. A Systronics UV-VIS double beam Spectrophotometer model 118 with $1.00 \mathrm{~cm}$ optical path quartz cells was employed to carry out the spectrophotometric studies.

\section{Results and discussion}

Chromium reacts with $m$-hydroxy benzyl ethylene diamine and forms a blood red colored complex at $\mathrm{pH}$ 6.5. The complex has a maximum absorbance at $550 \mathrm{~nm}$. The complex is stable for more than four hours. Hence, a detailed study of the extraction of chromium with $m$-hydroxy benzyl ethylene diamine has been undertaken with a view to develop a rapid and sensitive extractive spectrophotometric method for the determination of chromium in various water samples.

\subsection{Absorption Spectrum}

$1.0 \mathrm{ml}$ of chromium solution containing about $87.5 \mu \mathrm{g}$ of metal ion was transferred into a $25 \mathrm{ml}$ standard flask and to it, $3.0 \mathrm{ml}$ of buffer ( $\mathrm{pH} 7.0$ ), $2.0 \mathrm{ml}$ of $0.5 \mathrm{M} \mathrm{m}$-hydroxy benzyl ethylene diamine solutions were added to it and the volume of the aqueous phase was made up to $10.0 \mathrm{ml}$ with double distilled water. The absorption spectrum of the reagent complex is shown in Fig. 2. Maximum absorbance is observed at $550 \mathrm{~nm}$ and hence, all further absorbance measurements of the complex are made at $550 \mathrm{~nm}$.

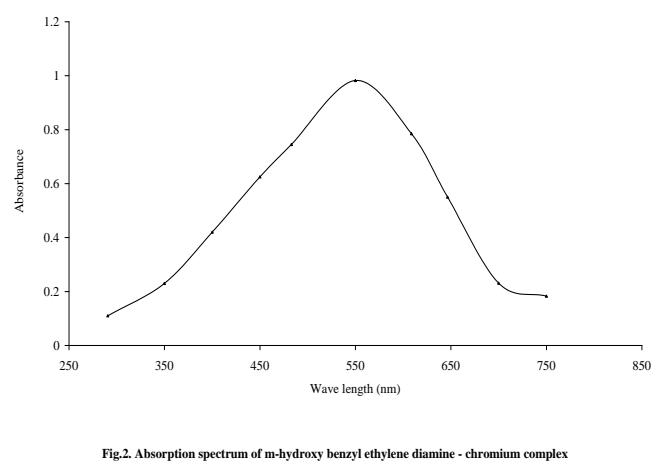

\section{Choice of solvent}

Various organic solvents such as MIBK, n-butanol, Benzene, Chloroform, Carbontetrachloride, Ethyl acetate, etc, were used for the extraction of reagent-metal complex. Maximum absorbance was obtained for Methyl Iso Butyl Ketone (MIBK). Hence, MIBK solvent was chosen for further investigations.

\subsection{Effect of $\mathbf{p H}$}

The effect of $\mathrm{pH}$ on the formation of chromium- $m$-hydroxy benzyl ethylene diamine complex was studied by keeping $1.0 \mathrm{ml}$ of $0.5 \mathrm{M}$ chromium solution and $2.0 \mathrm{ml}$ of $0.5 \mathrm{M} \mathrm{m}$-hydroxy benzyl ethylene diamine solution constant and varying the $\mathrm{pH}$ values of aqueous phases from 2.0 to 9.0 using suitable buffer solutions and the values are shown in Fig.3. As maximum absorbance is obtained with sodium acetate-acetic acid buffer at $\mathrm{pH}$ 6.5 further studies are continued keeping 6.5 as the optimum $\mathrm{pH}$.

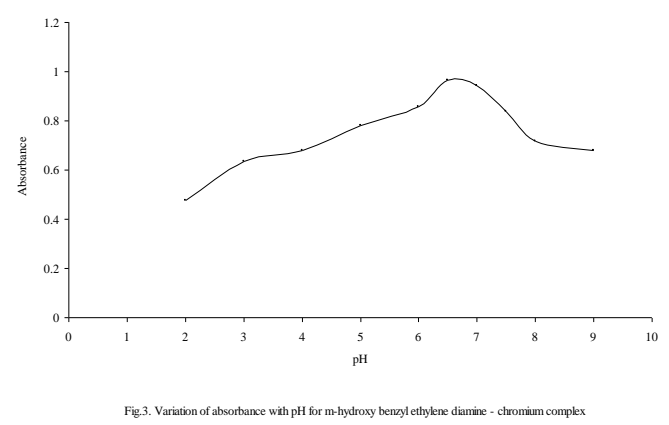

\subsection{Effect of reagent concentration}

The effect of the reagent concentration has been studied by using different solutions containing $1.0 \mathrm{ml}$ of chromium solution and $3.0 \mathrm{ml}$ of $\mathrm{pH} 6.5$ buffer solutions. To these solutions $1.0 \mathrm{ml}$ of the reagent solution containing varying concentrations from $0.5 \mathrm{M}$ to $4.0 \mathrm{M}$ was added to get maximum color formation. Maximum 
absorbance value was obtained at $0.5 \mathrm{M}$ which as seen from Fig. 4 . Hence, a $0.5 \mathrm{M}$ of the reagent solution is maintained for all further experimental studies.

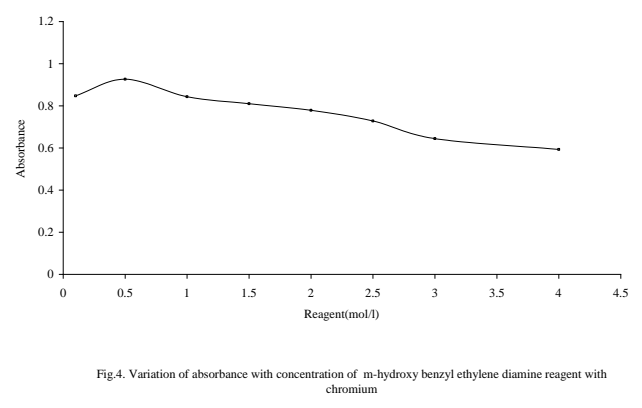

\subsection{Interference of non-target ions}

The effect of various species on the determination of chromium was investigated. The tolerance limit was taken as the amount that caused $\pm 2 \%$ absorbance error in determination of $2.0 \mu \mathrm{g}$ $\mathrm{ml}-1$ of chromium. The results are shown in Table.1.

Table.1. Effect of foreign species

\begin{tabular}{|l|l|}
\hline Species & $\begin{array}{l}\text { Tolerance limit } \\
{\left[\mu \mathrm{g} \mathrm{ml} \mathbf{~}^{-1}\right]}\end{array}$ \\
\hline $\mathrm{EDTA}$ & 520 \\
\hline $\mathrm{Na}^{+}, \mathrm{Mg}^{2+}, \mathrm{Cl}^{-}, \mathrm{NO}_{3}^{-}, \mathrm{F}, \mathrm{CHCOO}^{-}, \mathrm{CO}_{3}^{2-}, \mathrm{K}^{+}$ & 230 \\
\hline $\mathrm{Ba}^{2+}, \mathrm{SO}_{4}^{2-}, \mathrm{CN}^{-}, \mathrm{SCN}^{-}$, Tartarate & 80 \\
\hline $\mathrm{PO}_{4}^{3-}, \mathrm{Al}^{3+}, \mathrm{Cd}^{2+}, \mathrm{NO}_{2}^{-2}$ & 60 \\
\hline $\mathrm{Cu}^{2+}, \mathrm{Ni}^{2+}, \mathrm{Co}^{2+}, \mathrm{Ca}^{2+}$ & 14 \\
\hline $\mathrm{Zn}^{2+}, \mathrm{Pb}^{2+}, \mathrm{SO}_{3}{ }^{2-}, \mathrm{NO}_{3}^{-}, \mathrm{As}^{5+}$ & 12 \\
\hline $\mathrm{Fe}^{2+}, \mathrm{S}^{2-}$ & 5 \\
\hline
\end{tabular}

${ }^{\mathrm{a}}$ Can be masked with $1 \mathrm{ml}$ of $2 \%$ sulfamic acid.

\subsection{Sensitive and Molar Absorptivity}

The molar absorptivity of the complex was calculated to be as $2.14 \times 10^{4}$ lit $\mathrm{mol}^{-1} \mathrm{~cm}^{-1}$ and the Sandell's sensitivity of the complex was $2.672 \times 10^{-3} \mathrm{~cm}^{-2} \mu \mathrm{g}$.

\subsection{Stability of the Color Reaction}

The absorbance values of chromium- $m$-hydroxy benzyl ethylenediamine complex were noted at different intervals of time at $560 \mathrm{~nm}$. It was observed that the absorbance remained constant up to four hours.

\section{Applications of the developed method}

The proposed method was applied for the determination of chromium in water and industrial effluent samples.

\section{Procedure}

Transfer a sample aliquot, $1-10 \mathrm{ml}$ of solution containing up to $50 \mu \mathrm{g}$ chromium, to a $125 \mathrm{ml}$ separatory funnel. Add $1.0 \mathrm{ml}$ of $2.0 \mathrm{M}$ sulfuric acid and sufficient water to reach a final volume of about $10 \mathrm{ml}$. Add 10 $\mathrm{ml}$ of MIBK. Cool the funnel and its contents in an ice water bath at $10^{\circ} \mathrm{c}$ for $30 \mathrm{~min}$. All reagents added beyond this point are also cooled to $10^{\circ} \mathrm{C}$. Add $2.0 \mathrm{ml}$ of $3.0 \%(\mathrm{v} / \mathrm{v})$ hydrogen peroxide. Shake the funnel vigorously for $30 \mathrm{~s}$, allow for layer separation, and discard the aqueous phase. Add $5 \mathrm{ml} 0.01 \%$ (w/v) reagent. Again extract for $30 \mathrm{~s}$, allow for layer separation, and discard the aqueous phase. Transfer the organic phases to a $25 \mathrm{ml}$ volumetric flask, warm to room temperature, and add sufficient additional MIBK to achieve a volume of exactly $25 \mathrm{ml}$. Measure the absorbance of this solution against a reagent blank prepared in the same manner but containing no chromium.

\subsection{Analysis of water samples}

Samples were collected from industrial areas in and around Tirupati. Pre-treatment of waste water samples was done, as per the standard procedure, and analysed for chromium by the present analytical procedure. The results are shown in Table.2. 
Table.2. Determination of chromium in various water samples

\begin{tabular}{|c|c|c|c|}
\hline \multirow[b]{2}{*}{ Sample } & \multirow{2}{*}{$\begin{array}{l}\text { Chromium } \\
\text { added ( } \mu \mathrm{g} \mathrm{ml} \\
\mathbf{1}^{-}\end{array}$} & \multicolumn{2}{|c|}{ Proposed method } \\
\hline & & Found $^{\mathrm{a}}$ & $\begin{array}{l}\text { Recovery } \\
(\%)^{\mathrm{a}}\end{array}$ \\
\hline \multirow{4}{*}{$\begin{array}{l}\text { Drinking } \\
\text { water }^{b}\end{array}$} & - & $0.32 \pm 0.02$ & - \\
\hline & 0.8 & $1.10 \pm 0.04$ & 98.20 \\
\hline & 1.2 & $1.44 \pm 0.03$ & 94.73 \\
\hline & 1.8 & $2.09 \pm 0.01$ & 98.58 \\
\hline \multirow{3}{*}{$\begin{array}{l}\text { Natural } \\
\text { water }^{c}\end{array}$} & - & $0.46 \pm 0.02$ & - \\
\hline & 1.0 & $1.42 \pm 0.01$ & 97.26 \\
\hline & 1.5 & $1.90 \pm 0.04$ & 96.94 \\
\hline \multirow{2}{*}{$\begin{array}{l}\text { Polluted } \\
\text { water }^{\mathrm{d}}\end{array}$} & - & $0.18 \pm 0.04$ & - \\
\hline & - & $0.26 \pm 0.02$ & - \\
\hline \multirow{2}{*}{$\begin{array}{l}\text { Bore } \\
\text { water }^{\mathrm{e}}\end{array}$} & - & $0.80 \pm 0.06$ & - \\
\hline & 1.2 & $1.95 \pm 0.02$ & 97.50 \\
\hline
\end{tabular}

a) Mean \pm standard deviation $(n=6)$, b) Collected from municipal water supply, Tirupati, c) Collected from Swarnamukhi river, Srikalahasti, A.P, India. d) Collected from Renigunta Industrial area, A.P., India, e) Collected from In and Around Tirupati.

The estimation of chromium in different samples is done with the present reagent as well as with another standard reagent Ethylene diamine and the values are compared in Table 3. The results very well show the suitability of the developed reagent for extraction and estimation of chromium in water samples in an accurate manner.

Table 3. Comparision of present method with standard method

\begin{tabular}{|c|c|c|c|}
\hline Sample & Standard method $^{\mathrm{a}}$ & $\begin{array}{l}\text { Present } \\
\text { method }\end{array}$ & Recovery (\%) \\
\hline Drinking water ${ }^{\mathrm{b}}$ & 0.39 & $0.35 \pm 0.02$ & 90.00 \\
\hline Natural water ${ }^{\mathrm{c}}$ & 0.48 & $0.46 \pm 0.02$ & 96.00 \\
\hline Polluted water ${ }^{\mathrm{d}}$ & 0.26 & $0.19 \pm 0.04$ & 73.00 \\
\hline Bore well water & 0.88 & $0.80 \pm 0.06$ & 91.00 \\
\hline
\end{tabular}

a) Using Ethylene diamine procured from local market, b) Collected from municipal water supply, Tirupati. c) Collected from Swarnamukhi river, Srikalahasti, A.P., India. d) Collected from Renigunta Industrial area, A.P., India. e) Collected from In and Around Tirupati.

\section{Conclusions}

A thorough literature survey revealed that many reagents were used for the determination of chromium in various samples. But the studies on the use $m$-hydroxy benzyl ethylenediamine as an analytical reagent are limited. Hence, the present investigations were carried out with $m$-hydroxy benzyl ethylene diamine as a complexing agent for chromium determination in various samples by spectrophotometry. The method has good sensitivity and accuracy comparable with other existing extractive spectrophotometric determination methods. Finally, the developed method can be conclusively declared for the determination of chromium in various water samples.

\section{Acknowledgement}

The author would like to acknowledge the support provided by P.Nagaraju for sample collection. In addition the author would like to acknowledge K.Janardhanam, Department of Environmental Sciences, using their instruments. 


\section{References}

[1] S. Matsuoka, Y. Tennichi, K. Takehara, and K. Yoshimura, Flow analysis of micro amounts of chromium (III) and (VI) in natural water by solid phase spectrophotometry using diphenylcarbazide, Analyst, 124, 1999, 787-791.

[2] Y. Luo, S. Nakano, D.A. Holman, J. Ruzicka and G.D.Crhistian, sequential injection wetting film extraction applied to the spectrophotometric determination of Chromium (VI) and Chromium (III) in water, Talanta, 44, 1997, $1563-68$.

[3] Environmental Protection Agency, Toxicological review of trivalent chromium (CAS no. 16065-83-1) in support of summary information on the integrated risk information system (IRIS), US Environmental Protection Agency, Washington, DC, 1998.

[4] J.O.Nriagu and E.Nieboer, (Eds.), Chromium in Natural and Human Environment, Wiley, New York, 1988.

[5] B.Demirata, I.Tor, H.Filik and H.Afar, separation of $\mathrm{Cr}$ (III) and $\mathrm{Cr}$ (VI) using melamine-farmaldehyde resin and determination of both species in water by FAAS, Fresenius, J. Anal. Chem. 356, 1996, 375-377.

[6] E.B.Gonzalez, J.B.Garcya, P.B.Barreta and A.B.Barreta, Separation of Cr(III) and $\mathrm{Cr}(\mathrm{VI})$ using complexation of Cr(III) with 8hydroxyquinoline and determination of both species in waters by ETAAAS, Fresenius J. Anal. Chem. 344, 1992, 301-305.

[7] D.M.A.Cerezo, M.L.Esteles and A.R.M.Aucejo, Preconcentration and speciation of chromium in waters using solid phase extraction and atomic absorption spectrometry, Talanta 51, 2000, 531-536.

[8] B.Pasullean, C.M.Davoson and D.Littlejohn, Online preconcentration of chromium (III) and speciation of chromium in waters by flame atomic absorption spectrometry, J. Anal. At. Spectrom 10, 1995, 241-246.

[9] J.Ueda, H.Sato and S.Kagaya, Determination of Chromium (III) and Chromium (VI) by Graphite furnace Atomic Absorption Spectrometry after coprecipitation with Hafnium hydroxide, Anal. Sci. 13(4), 1997, 613-617.

[10] G.M.Wuilloud, R.G.Wuilloud, J.C.A.de Wuilloud, R.A.Olsina and L.D.Martinez, Online preconcentration determination of chromium in parenteral solutions by flow injection flame atomic absorption spectrometry, J. Pharm. Biomed. Anal. 31, 2002, 117-124.

[11] H.D.Revanasiddappa and T.N.Kiran Kumar, Rapid spectrophotometric determination of chromium with trifluoperazine hydrochloride, Chem. Anal. (Warsaw), 47, 2002, 311-313.

[12] F.Sabermahani and M.A.Taher, Polyacrylic acid-modified alumina for solid-phase extraction and preconcentration of trace iron and chromium from plant samples, J AOAC Int. 94(6), 2011, 1918-24.

[13] P.Sabhapandit and A.K.Mishra, Physico-chemical characteristics of ground and surface water in Gohpur sub-division of Sonitpur district, Assam (India), J Environ Sci Eng., 53(1), 2011, 89-96.

[14] C.D. Pereira, J.G.Techy, E.M.Ganzarolli and S.P.Quináia, Chromium fractionation and speciation in natural waters, J Environ Monit. 30;14(6), 2012,1559-64.

[15] M. Hashemi and S.M.Daryanavard, Ultrasound-assisted cloud point extraction for speciation and indirect spectrophotometric determination of chromium(III) and (VI) in water samples, Spectrochim Acta A Mol Biomol Spectrosc., 15;92, 2012,189-93.

[16] O.Findik and M.A.Turan, Metal concentrations in surface sediments of Beyler reservoir (Turkey), Bull Environ Contam Toxicol. 88(2), 2012, 193-7. 